\title{
Effect of Volatile Fatty Acid Concentration on Anaerobic Degradation Rate from Field Anaerobic Digestion Facilities Treating Food Waste Leachate in South Korea
}

\author{
Dong-Jin Lee, ${ }^{1}$ Su-Young Lee, ${ }^{1}$ Ji-Su Bae, ${ }^{1}$ Jung-Gu Kang, ${ }^{1}$ Ki-Heon Kim, ${ }^{1}$ Sung-Su Rhee, \\ Jong-Hwan Park, ${ }^{2}$ Ju-Sik Cho, ${ }^{3}$ Jin Chung, ${ }^{1}$ and Dong-Cheol Seo ${ }^{3}$ \\ ${ }^{1}$ Environmental Resources Research Department, National Institute of Environmental Research, Environmental Research Complex, \\ Incheon 404-708, Republic of Korea \\ ${ }^{2}$ Division of Applied Life Science (BK21 Plus) and Institute of Agriculture and Life Science, Gyeongsang National University, \\ Jinju 660-701, Republic of Korea \\ ${ }^{3}$ Department of Bio-Environmental Sciences, Sunchon National University, Suncheon 540-742, Republic of Korea
}

Correspondence should be addressed to Jin Chung; dongj77@naver.com and Dong-Cheol Seo; drseodc@gmail.com

Received 5 February 2015; Accepted 17 April 2015

Academic Editor: Jimmy T. Efird

Copyright (C) 2015 Dong-Jin Lee et al. This is an open access article distributed under the Creative Commons Attribution License, which permits unrestricted use, distribution, and reproduction in any medium, provided the original work is properly cited.

\begin{abstract}
The purpose of this study was to investigate the effect of volatile fatty acid concentration on anaerobic degradation rate of food waste leachate in the anaerobic digestion facilities. The anaerobic digestion facilities treating food waste leachate (FWL), codigestion with food leachate and animal manure (A-MIX), and codigestion with food waste leachate and sewage sludge (S-MIX) were selected for this study. In accordance with the regulation under Wastes Control Act in South Korea, the guideline of volatile solid removal rate for anaerobic digestion facility is set as $65 \%$ for anaerobic degradation efficiency. Highest volatile solids removal rates were achieved from FWL (63.5\%) than A-MIX (56.4\%) and S-MIX (41.2\%). Four out of eight FWLs met the guidelines. The concentration of volatile fatty acids, therefore, was analyzed to determine the relationship with volatile solid removal rate. The results showed that, in order to meet the Korean guideline of $65 \%$ volatile solid removal rate, volatile fatty acid concentrations should remain below $4,000 \mathrm{mg} / \mathrm{L}$ on the field anaerobic digestion facilities treating FWL. Volatile fatty acid concentrations should be used along with others as an operational parameter to control and manage the anaerobic digestion process.
\end{abstract}

\section{Introduction}

Before ban of direct landfill of food waste was imposed in South Korea, more than $90 \%$ of food waste was landfilled and the rest was treated by composting, incineration, feeding livestock, and anaerobic digestion $[1,2]$. Landfilling of food waste has been banned in Korea since 2005 because of problems of leaching and odour from landfilling of food waste $[1,3]$. Ocean dumping of food wastes has also been banned since 2012 in compliance with the London Convention and Protocol [4]. Effective treatment option for organic waste has been sought thereafter.

Anaerobic digestion treatment has been one of the effective treatment options for biodegradable organic waste including food waste/food waste leachate, animal manure, and sewage sludge as it effectively reduces the amount of organic waste and produces biogas as a renewable energy $[3,5]$.

Food waste is a good resource for anaerobic digestion treatment because it contains high organic matter with appropriate moisture content [2] and it is easily biodegradable $[3,6]$. Animal manure provides high buffering capacity [7]; therefore, it has been often treated by anaerobic codigestion with sewage sludge and/or food waste [8-10]. Because of its low concentration of organic matters, sewage sludge has been known to produce low amount of biogas compared to anaerobic digestion of food waste and animal manure [2]. It often has been treated by anaerobic codigestion with food waste to improve anaerobic degradation efficiency [2]. There have been many studies on improving its degradation efficiency by 
anaerobic codigestion of animal manure and sewage sludge with food waste. Some of them are on anaerobic codigestion system with food waste, animal manure, and sewage sludge [10], anaerobic digestion system with food waste and sewage sludge [11-13], and anaerobic codigestion system with food waste and animal manure $[14,15]$. These studies were based on bench- or pilot-scales. More analysis of the process in the actual facilities is required to understand and monitor the efficiency.

There currently are 57 anaerobic digestion/codigestion facilities nationwide, and they are either at conventional wastewater treatment plants or at separate anaerobic digestion/codigestion plants for the organic fraction of municipal solid waste (OFMSW), mainly food waste/food waste leachate in South Korea [16].

Anaerobic digestion involves a series of metabolic reactions (hydrolysis, acidogenesis, and methanogenesis) [17, 18]. Among these intermediate products of anaerobic digestion, two volatile fatty acids (acetic acid and butyric acid) are among the most favored for methane formation while acetic acid contributes more than $70 \%$ to the methane formation [19]. Namely, acetic acid, butyric acid, isobutyric acid, isovaleric acid, and propionic acid have been known as good indicators for monitoring performance of anaerobic digestion process, especially in the activity of acetogenic and methanogenic bacteria [17, 19-22]. Additionally, various physicochemical parameters $(\mathrm{pH}$, temperature, alkalinity, volatile fatty acid, retention time, biogas, etc.) influence these reactions [23-25]. The complexity of the process made the interpretation of the performance of the process difficult; therefore a combination of those parameters was suggested as a better method for monitoring the performance of the process [26].

In South Korea, the anaerobic digestion facilities treating food waste and food waste leachate have been regulated by the Wastes Control Act and volatile solid removal rate for anaerobic digestion facility is set as $65 \%$ in accordance with the guidelines for anaerobic degradation efficiency [16].

Therefore, the objective of this paper was not only to identify the parameters that can be used to determine the performance of the anaerobic digestion process in terms of anaerobic degradation efficiency in South Korea but also specifically to investigate the effect of the volatile fatty acid concentration on anaerobic degradation rate of food waste leachate in these anaerobic digestion facilities.

\section{Materials and Methods}

2.1. Selection of Facilities and Sampling. Seventeen anaerobic digestion/codigestion facilities at conventional wastewater treatment plants and at separate anaerobic digestion/codigestion plant for OFMSW were selected for this investigation. These facilities were treating more than $50 \mathrm{t} / \mathrm{d}$ of feedstock rate. They include 8 facilities treating food waste leachate (FWL 1 FWL 7), 3 anaerobic codigestion facilities with a mixture of animal manure and food waste leachate (AMIX 1 A-MIX 3), and 6 anaerobic codigestion facilities with a mixture of sewage sludge and food waste leachate (S-MIX
1 S-MIX 6). The types of feed waste and the digestion system were presented in Table 1.

Samples for analysis were collected from the inlet and outlet valves of anaerobic digester at each facility. And they were kept refrigerated until they were analyzed.

2.2. Analytical Methods. Total solids, moisture content, and volatile solids were determined according to Standard Methods 1684 [26]. CODcr was analyzed according to closed reflux, titrimetric method $(5220 \mathrm{C})$ and $\mathrm{NH}_{4}{ }^{+}-\mathrm{N}$ and $\mathrm{T}-\mathrm{N}$ were analyzed according to Standard Methods 4500 [26] and standard methods for testing water [35].

Volatile fatty acids were analyzed according to Standard Methods (5560 D-Gas chromatographic method) [26, 36, 37]. The concentration of each volatile fatty acid, namely, acetic acid, propionic acid, isobutyric acid, butyric acid, isovaleric acid, and valeric acid, was conducted by gas chromatography (Agilent 6890, USA; column: DB-FFAP, $25 \mathrm{~m} \times 0.32 \mathrm{~mm} \times$ $0.5 \mu \mathrm{m}$; oven temperature program: $2 \mathrm{~min}, 95^{\circ} \mathrm{C}, 2 \mathrm{~min}, 140^{\circ} \mathrm{C}$ at $10^{\circ} \mathrm{C} / \mathrm{min}$, and $5 \mathrm{~min}, 240^{\circ} \mathrm{C}$ at $40^{\circ} \mathrm{C} / \mathrm{min}$; injection temperature: $240^{\circ} \mathrm{C}$; injection mode: split $(10: 1)$; flow: $\left.1.0 \mathrm{~mL} / \mathrm{min}\right)$ equipped with FID detector. Helium was used as a carrier gas. Samples were acidified to $\mathrm{pH} 2$ with phosphoric acid and centrifuged at $3500 \mathrm{rpm}$ for $5 \mathrm{~min}$. The supernatant was extracted with $1 \mathrm{~g}$ of $\mathrm{NaCl}$ and diethyl ether after vortexing for $5 \mathrm{~min}$ before being analyzed with GC-FID.

\section{Results and Discussion}

3.1. Characteristics of Feed Waste. Table 2 shows the physicochemical characteristics of feed wastes. The moisture content, fixed solids, and volatile solids of individual feed waste were presented in Figure 1. Total solids content in FWL from 8 anaerobic digestion facilities varied from $3.6 \%$ to $12.2 \%$ with the average total solids content of $7.2 \%$. Volatile solid content in FWL from 8 anaerobic digestion facilities varied from $1.8 \%$ to $10.4 \%$ with the average volatile solid content of $5.5 \%$. Total solid content in A-MIX from 3 anaerobic digestion facilities varied from $4.3 \%$ to $5.3 \%$ with the average total solid content of $4.6 \%$, and volatile solid content in A-MIX from 3 anaerobic digestion facilities varied from $3.0 \%$ to $3.7 \%$ with the average volatile solid content of $3.3 \%$. Total solid content in S-MIX from 6 anaerobic digestion facilities varied from $3.1 \%$ to $9.4 \%$ with the average total solid content of $5.0 \%$, and volatile solid content in S-MIX from 6 anaerobic digestion facilities varied from $2.0 \%$ to $7.4 \%$ with the average volatile solid content of $3.5 \%$. The highest total solid and volatile solid content were from FWL as expected. The volatile solid content in total solids (volatile solid/total solids) from all types of feed wastes was 71.0, 72.0, and 71.5\% for FWL, A-MIX, and S-MIX, respectively. Volatile solid/total solid presents the amount that is biodegradable in total solid. The physicochemical characteristics of three types of feed waste from the literature are presented in Table 3. Borowski and Weatherley [38] also observed similar percentage of volatile solid in total solid (volatile solid/total solids) for poultry manure and sewage sludge, even though animal manure contained higher total solid and volatile solid than those in sewage sludge. Volatile 
TABLE 1: Operating conditions of selected anaerobic digestion facilities.

\begin{tabular}{|c|c|c|c|c|}
\hline Types of feed waste & $\begin{array}{c}\text { Individual anaerobic digestion } \\
\text { facility }\end{array}$ & Mixing ratio* & $T\left({ }^{\circ} \mathrm{C}\right)$ & Types of system ${ }^{* *}$ \\
\hline \multirow{8}{*}{ Food waste leachate (FWL) } & FWL1 & 1 & 55 & 2 \\
\hline & FWL2 & 1 & 35 & 2 \\
\hline & FWL3 & 1 & 35 & $-^{* * *}$ \\
\hline & FWL4 & 1 & 35 & 1 \\
\hline & FWL5 & 1 & 35 & - \\
\hline & FWL6 & 1 & 55 & 1 \\
\hline & FWL7 & 1 & 55 & - \\
\hline & FWL8 & 1 & - & 2 \\
\hline \multirow{3}{*}{$\begin{array}{l}\text { Animal manure }+ \text { food waste } \\
\text { leachate (A-MIX) }\end{array}$} & A-MIX1 & $3: 1^{\dagger}$ & 35 & 1 \\
\hline & A-MIX2 & $7: 3$ & 55 & 1 \\
\hline & A-MIX3 & - & 35 & 2 \\
\hline \multirow{6}{*}{$\begin{array}{l}\text { Sewage sludge }+ \text { food waste leachate } \\
\text { (S-MIX) }\end{array}$} & S-MIX1 & $3: 2^{\ddagger}$ & 55 & 1 \\
\hline & S-MIX2 & $13: 1$ & 35 & 1 \\
\hline & S-MIX3 & $4.5: 1$ & 35 & 2 \\
\hline & S-MIX4 & $4: 1$ & 35 & 1 \\
\hline & S-MIX5 & $50: 1$ & 55,35 & 1 \\
\hline & S-MIX6 & $6.7: 1$ & 35 & 1 \\
\hline
\end{tabular}

${ }^{*}$ Ratio $=$ feed ratio into anaerobic digester. ${ }^{\dagger}$ Animal manure: food waste leachate for A-MIX, ${ }^{\ddagger}$ sewage sludge: food waste leachate for S-MIX. ${ }^{* *} 1$ : single stage system; 2 : two-stage system.

***_: unknown data.

TABle 2: Physicochemical characteristics of feed waste.

\begin{tabular}{lcccc}
\hline Parameters & & \multicolumn{3}{c}{ Types of feed waste } \\
& Unit & FWL & A-MIX & S-MIX \\
\hline Moisture content & $\%$ & $92.8(2.9)$ & $95.4(0.5)$ & $3.3(0.3)$ \\
Volatile solid & $\%$ & $5.5(3.0)$ & $4.6(0.5)$ & $3.5(1.8)$ \\
Total solids & $\%$ & $7.2(2.9)$ & $72.0(1.1)$ & $5.0(2.1)$ \\
Volatile solid/total solids ${ }^{*}$ & $\%$ & $71.0(15.1)$ & $4,744.0(5,260.0)$ & $71.5(9.5)$ \\
T-N & $\mathrm{mg} / \mathrm{L}$ & $3,190.5(953.0)$ & $777.1(979.9)$ & $4,914.4(2,406.0)$ \\
$\mathrm{NH}_{3}$-N & $\mathrm{mg} / \mathrm{L}$ & $686.7(749.3)$ & $9,115.0(2,957.5)$ & $98.8(372.0)$ \\
Total volatile fatty acid & $\mathrm{mg} / \mathrm{L}$ & $12,420.0(9,878.9)$ & & $3,679.5(4.6)$ \\
\hline
\end{tabular}

Mean values of 17 selected facilities and standard deviation in parentheses.

( $n=8$ for FWL, $n=3$ for A-MIX, and $n=6$ for S-MIX.)

${ }^{*}$ Volatile solid/total solids $=[$ Volatile solid $/($ Volatile solid + Fixed solid $)] \times 100$.

solid/total solids for fruit and vegetable wastes and food wastes in the literature (Table 3 ) were in the range of 82.5 $92.9 \%$ and they were higher than those found in this study. The discrepancy could be related to the different composition of food waste because of food/dietary habit in different geographical background. In addition many of food wastes and fruit and vegetable wastes were collected from one place, that is, restaurant or cafeteria which might produce the wastes with less variation than those from the municipal solid waste facilities. The physicochemical characteristics of S-MIX $(5.0 \%$ of total solids and $3.5 \%$ of volatile solid) in this study were higher than those of sewage sludge (3.5 4.9\% of total solids and $2.3 \sim 3.7 \%$ of volatile solid) in the literature (Table 3 ) because S-MIX in this study was mixed with food waste leachate.
3.2. Removal Rates of Volatile Solid and COD. The volatile solid removal rate from each anaerobic digestion facility with individual feed waste is presented in Figure 2. The guideline of anaerobic degradation efficiency in South Korea is stipulated to monitor the efficiency of the process. Figure 2(a) shows volatile solid removal rates of 17 anaerobic digestion facilities and the bold horizontal dashed line denotes the volatile solid removal rate of $65 \%$ as set forth in Wastes Control Act. Considering the types of feed waste, the average volatile solid removal rate of FWL was $63.4 \%$, and it was higher than volatile solid removal rate of A-MIX (56.4\%) and SMIX (41.2\%). Regarding FWL, 4 out of 8 anaerobic digestion facilities with food waste leachate achieved volatile solid removal rates greater than $65 \%$ and they were ranged from 78 to $88 \%$. Two out of 8 facilities with FWL achieved volatile 


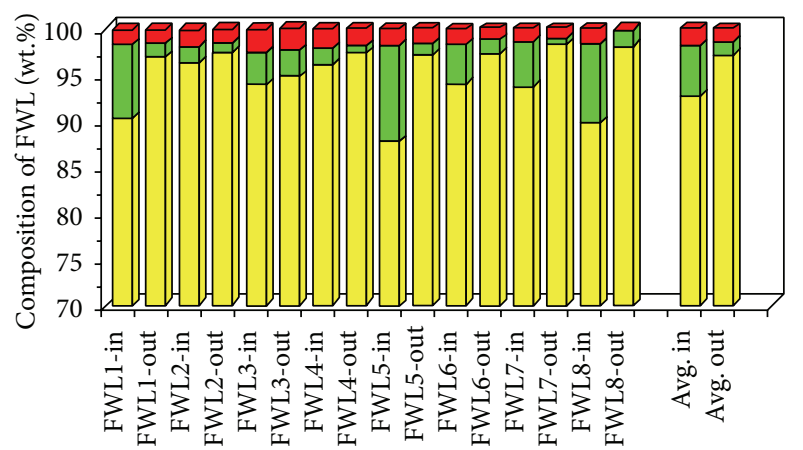

(a)

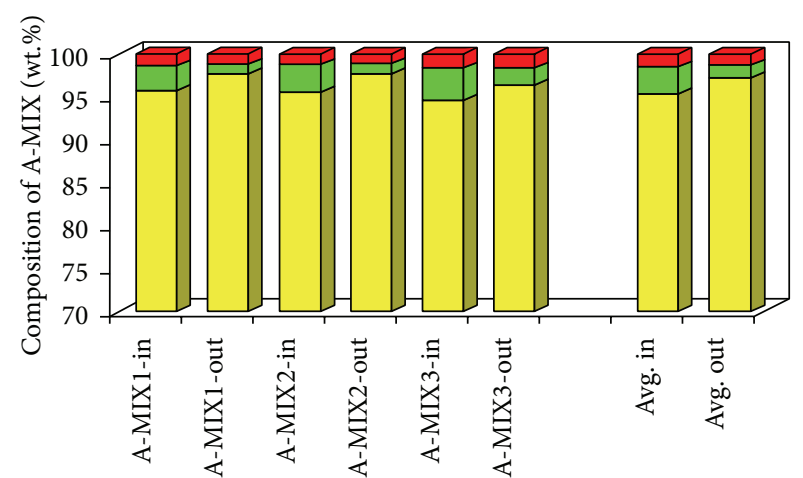

(b)

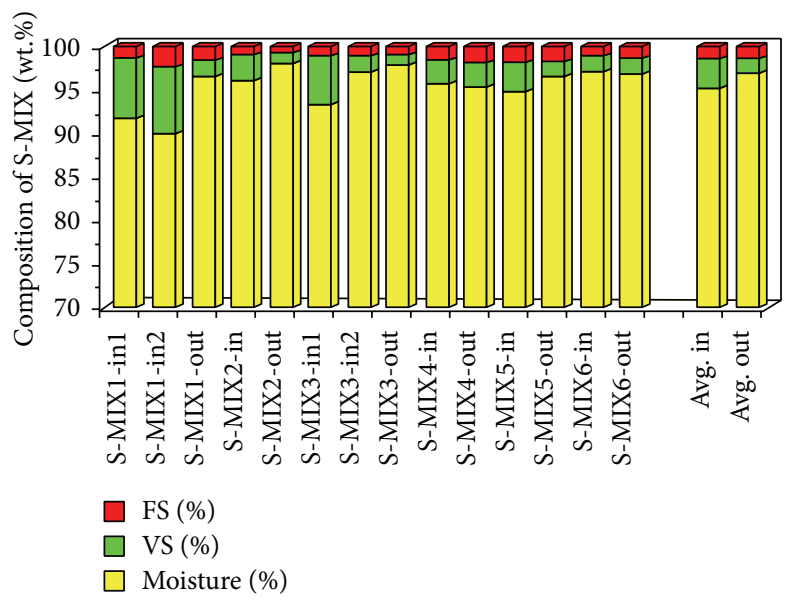

(c)

FIgure 1: Compositions of feed waste: (a) FWL; (b) A-MIX; (c) S-MIX.

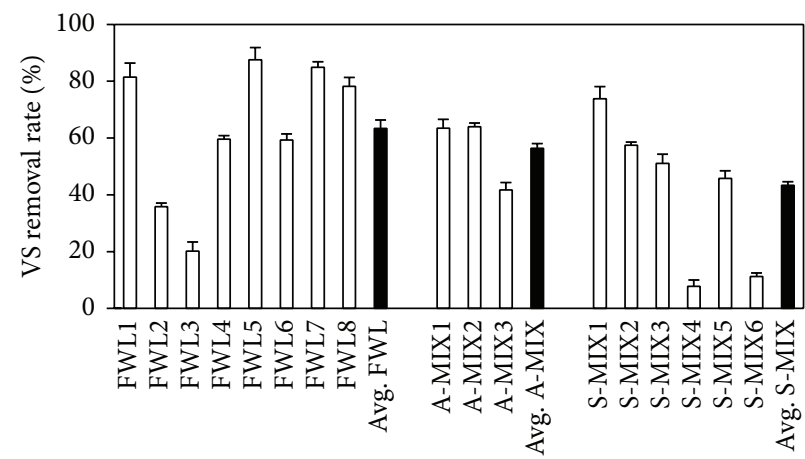

(a)

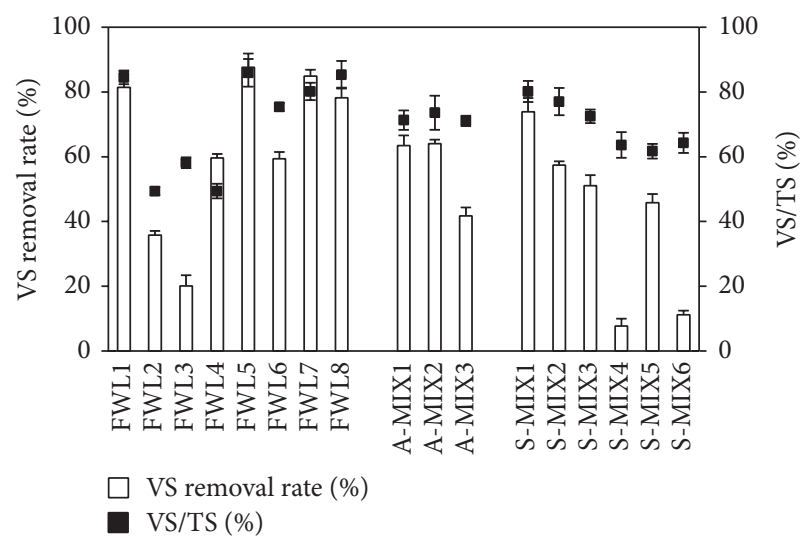

(b)

FIGURE 2: Volatile solid removal rates of individual anaerobic digestion facilities: (a) comparison with 65\% volatile solid removal rate of Korea Waste Act; (b) comparison with volatile solid/total solids.

solid removal rate just below 65\% (59 and 60\%). Regarding A-MIX, 2 out of 3 facilities reached volatile solid removal rate just below 65\% (63 and 64\%). Regarding S-MIX, 1 out of 6 facilities with S-MIX reached volatile solid removal rate over $65 \%(74 \%)$ and 3 out of 6 facilities with S-MIX operated at the volatile solid removal rate of 51 57\%.
Lee et al. [2] obtained a similar result of volatile solid removal rate ranging between 46.6 and $61.7 \%$ from a benchscale anaerobic codigestion reactor with food waste and sewage sludge. Reasonably high volatile solid removal rates with the range of $39.5 \sim 86.1 \%$ were observed from food waste in the literature (Table 3) and they are comparable 
TABLE 3: Total and volatile solid of food waste, animal (poultry, pig, and cow) manure, and sewage sludge and their VS removal rates in the literature.

\begin{tabular}{|c|c|c|c|c|c|}
\hline Waste & Total solids (\%) & $\begin{array}{c}\text { Volatile solid } \\
(\%)\end{array}$ & $\begin{array}{c}\text { Volatile solid/total } \\
\text { solids (\%) }\end{array}$ & $\begin{array}{c}\text { Volatile solid removal } \\
\text { rate }(\%)^{* *}\end{array}$ & References \\
\hline Poultry manure & $\begin{array}{l}28.9 \\
27.7\end{array}$ & $\begin{array}{l}21.5 \\
20.5\end{array}$ & $\begin{array}{l}72.7 \\
74.0\end{array}$ & $\begin{array}{c}43.1 \sim 49.4 \\
\text { (with sewage sludge) }\end{array}$ & $\begin{array}{l}\text { KMOE [16], McCarty } \\
\text { and Smith [27] }\end{array}$ \\
\hline \multirow[t]{2}{*}{ Pig manure } & 9.2 & 7.0 & 76.1 & - & \multirow{2}{*}{ Borowski et al. [28] } \\
\hline & 12.4 & 9.0 & 72.6 & $\begin{array}{c}23.9 \sim 32.5 \\
\text { (with sewage sludge) }\end{array}$ & \\
\hline \multirow{3}{*}{ Cow/dairy manure } & 26.7 & 22.5 & 84.3 & - & Anjum et al. [29] \\
\hline & 13.8 & 11.0 & 79.9 & - & Scano et al. [30] \\
\hline & $\begin{array}{l}17.1 \\
9.2\end{array}$ & $\begin{array}{l}16.3 \\
13.2\end{array}$ & $\begin{array}{l}84 \\
81\end{array}$ & $\frac{-}{-}$ & Zhang et al. [15] \\
\hline \multirow{4}{*}{$\begin{array}{l}\text { Fruit and vegetable } \\
\text { wastes }\end{array}$} & 12.7 & 11.0 & 86.6 & - & Anjum et al. [29] \\
\hline & $3.4 \sim 21.8$ & $2.7 \sim 20.4$ & - & - & Borowski et al. [28] \\
\hline & $4.4 \sim 4.5$ & $3.9 \sim 4.0$ & - & 53 (no pH control) & Ganesh et al. [31] \\
\hline & $7.3 \sim 10.0$ & 9.7 & - & 70 (with pH control) & An et al. [6] \\
\hline \multirow{9}{*}{$\begin{array}{l}\text { Composite food waste } \\
\text { (grain, fish, meat, } \\
\text { fruit, and vegetable) }\end{array}$} & 27.5 & 22.7 & 82.5 & - & Lee et al. [2] \\
\hline & $3.0 \sim 4.5$ & $2.9 \sim 4.3$ & - & - & Ganesh et al. [31] \\
\hline & 22.4 & 18.9 & 84.4 & $\begin{array}{l}39.5 \text { (with activated } \\
\text { waste sludge and } \\
\text { mesophilic) }\end{array}$ & $\begin{array}{l}\text { El-Mashad and Zhang } \\
{[32]}\end{array}$ \\
\hline & $18.0 \sim 23.0$ & $16.4 \sim 21.9$ & - & $74.1 \sim 86.1$ & Kim et al. [12] \\
\hline & $7.0 \sim 20.0$ & $6.6 \sim 19.0$ & - & - & Cabbai et al. [33] \\
\hline & 28.0 & 24.1 & 85.0 & & Scano et al. [30] \\
\hline & 30.9 & 26.4 & 92.0 & - & Cabbai et al. [33] \\
\hline & 18.5 & 17.0 & 92.9 & - & Zhang et al. [15] \\
\hline & 24.8 & 23.0 & - & $68.3 \sim 80.6$ & Cavinato et al. [34] \\
\hline \multirow{3}{*}{ Sewage sludge } & $4.7 \sim 4.9$ & $3.5 \sim 3.7$ & 74.1 & $33.9 \sim 36.3$ & $\begin{array}{l}\text { KMOE [16], McCarty } \\
\text { and Smith [27] }\end{array}$ \\
\hline & 3.5 & 2.3 & 65.7 & - & Ganesh et al. [31] \\
\hline & 3.8 & 2.3 & 60.5 & - & $\begin{array}{l}\text { El-Mashad and Zhang } \\
\text { [32] }\end{array}$ \\
\hline
\end{tabular}

Only those types of waste relevant to the Korean dietary habit were considered and those green wastes (grass, wood, etc.) were not included.

${ }^{*}$ Composite food wastes were mainly collected from household, restaurant, canteen, and cafeteria.

** Pilot-scale and lab-scale; - : data unavailable.

with volatile solid removal rate of FWL (avg. 63.5\%) in this study. The second highest volatile solid removal rates were achieved with A-MIX (avg. 56.4\%) in this study and the result was higher than the volatile solid removal rate with animal manure in the literature (23.9 49.4\%). The lowest volatile solid removal rate was observed from S-MIX (avg. 41.2\%) and the result was also higher than the result in the literature (26.8 38.2\%). The reason for higher volatile solid removal rates observed from A-MIX and S-MIX in this study was due to the codigestion with food waste leachate. The result surely could not be directly compared with the results in the literature due to different operational systems and conditions; however the trend in volatile solid removal rate achieved from food waste leachates in this study was comparable with the results in the literature (Table 3).

Higher volatile solid generally means higher amount of organic materials that are convertible to biogas. Also higher volatile solid/total solids increased the amount of biodegradable materials and it would cause the increase of the microbial activities, thereby increasing volatile solid removal rate [38]. Figure 2(b) indicated a reasonable trend of increasing volatile solid removal rates with increasing volatile solid/total solids. In the current study, volatile solid/total solids of three types of feed waste, such as FWL, A-MIX, and S-MIX, were analyzed within the average range of 71.0 72.0\% and they agreed with volatile solid/total solids in the literature (Table 3). Therefore the performance of anaerobic digestion was related to the volatile solid/total solids.

COD concentrations of input and output of each anaerobic digestion facility are presented in Figure 3. Average COD concentration of FWL in inlet ("FWL-In") was $85,169 \mathrm{mg} / \mathrm{L}$, average COD concentration of A-MIX in inlet ("A-MIXIn") was $80,267 \mathrm{mg} / \mathrm{L}$, and average COD concentration of SMIX in inlet ("S-MIX-In") was $64,033 \mathrm{mg} / \mathrm{L}$. After anaerobic 
TABLE 4: Results of COD and VS removal rate.

\begin{tabular}{|c|c|c|c|}
\hline Types of feed waste & Individual anaerobic digestion facility & CODcr removal rate $(\%)$ & VS removal rate $(\%)$ \\
\hline \multirow{9}{*}{ FWL } & FWL1 & $79 \pm 5$ & $81 \pm 6$ \\
\hline & FWL2 & $58 \pm 2$ & $36 \pm 3$ \\
\hline & FWL3 & $14 \pm 1$ & $20 \pm 3$ \\
\hline & FWL4 & $72 \pm 3$ & $60 \pm 5$ \\
\hline & FWL5 & $92 \pm 6$ & $88 \pm 3$ \\
\hline & FWL6 & $53 \pm 4$ & $59 \pm 4$ \\
\hline & FWL7 & $83 \pm 3$ & $85 \pm 4$ \\
\hline & FWL8 & $78 \pm 4$ & $78 \pm 3$ \\
\hline & Mean $\pm \mathrm{SD}^{\#}$ & $66 \pm 13$ & $63 \pm 23$ \\
\hline \multirow{4}{*}{ A-MIX } & A-MIX1 & $35 \pm 2$ & $63 \pm 3$ \\
\hline & A-MIX2 & $83 \pm 6$ & $64 \pm 6$ \\
\hline & A-MIX3 & $71 \pm 5$ & $42 \pm 4$ \\
\hline & Mean $\pm \mathrm{SD}^{\#}$ & $63 \pm 20$ & $56 \pm 10$ \\
\hline \multirow{7}{*}{ S-MIX } & S-MIX1 & $83 \pm 3$ & $74 \pm 5$ \\
\hline & S-MIX2 & $65 \pm 5$ & $57 \pm 2$ \\
\hline & S-MIX3 & $51 \pm 5$ & $51 \pm 4$ \\
\hline & S-MIX4 & $85 \pm 6$ & $8 \pm 1$ \\
\hline & S-MIX5 & $39 \pm 4$ & $46 \pm 3$ \\
\hline & S-MIX6 & $24 \pm 3$ & $11 \pm 1$ \\
\hline & Mean \pm SD $^{\#}$ & $58 \pm 18$ & $41 \pm 24$ \\
\hline
\end{tabular}

${ }^{\#}$ Mean \pm standard deviation.

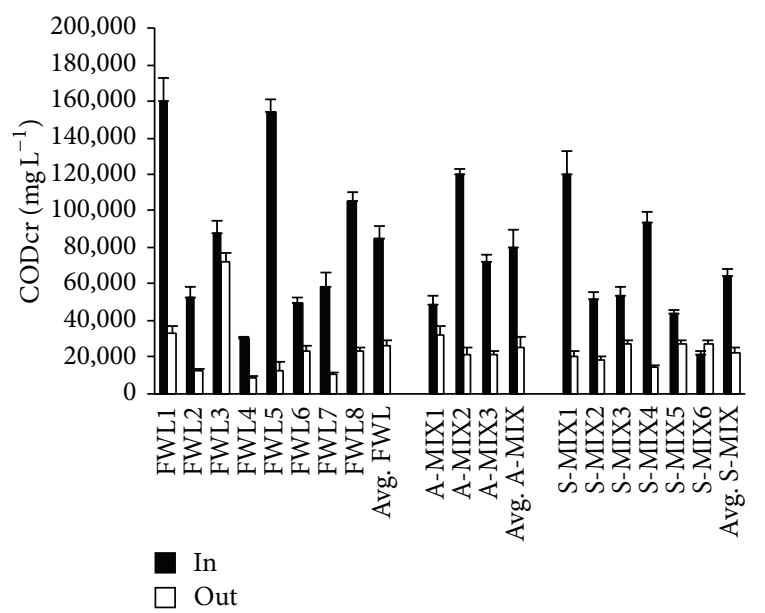

FIGURE 3: CODcr of each anaerobic digestion facility.

digestion treatment, COD removal rates for FWL, A-MIX, and S-MIX were found to be $66.1 \%, 62.6 \%$, and $57.8 \%$ (Table 4), respectively.

Although there is still a debate about whether the volatile solid removal rate of $65 \%$ set forth in Wastes Control Act is reasonable, the results from 17 anaerobic digestion facilities in South Korea agreed with those of the literature that the highest removal rate was observed with food waste while the lowest removal rate was observed with sewage sludge (Table 4).

3.3. Relationship between Volatile Fatty Acid Concentration and Anaerobic Degradation Rate. Figure 4 shows the concentration of 6 individual volatile fatty acids, namely, acetic acid, propionic acid, isobutyric acid, butyric acid, isovaleric acid, and valeric acid, found in inlet and outlet of each anaerobic digestion process. For FWL, the concentration of acetic acid was highest in feed waste, and the average concentration of acetic acid was $5,431 \mathrm{mg} / \mathrm{L}$. The high concentration of butyric acid was observed from feed waste of FWL2 and FWL3 (6,014 and 9,049 mg/L, resp.) and high concentration of propionic acid was also observed from feed waste of FWL2 and FWL4 (2,065 and 2,248 mg/L, resp.). This result agreed with Wijekoon et al. [19] who observed acetic acid and butyric acid as the predominant volatile fatty acid. High concentrations of propionic acid were relatively found in outlet from FWL2, FWL3, FWL4, and FWL6 (569, 1,282, 1,795, and $847 \mathrm{mg} / \mathrm{L}$, resp.). For A-MIX, the concentration of acetic acid was dominantly high in feed waste with the average concentration of $3,925 \mathrm{mg} / \mathrm{L}$. Concentration of propionic acid was high (average concentration of $1,751 \mathrm{mg} / \mathrm{L}$ ) in outlet of A-MIX3. For S-MIX, the concentration of acetic acid was observed to be the highest in feed (average of 2,218 mg/L). The highest concentration of acetic acid was observed from one of the inlets (denoted as "S-MIX3-In1" in Figure 4) of SMIX3 (11,213 mg/L) where food waste leachate was fed into the anaerobic digester (S-MIX3-In1) separately and sewage sludge was fed through other inlet (denoted as "S-MIX3In2" in Figure 4) of S-MIX3. Acetic acid has been known as an important intermediate for overall anaerobic digestion process as it is directly related to the end product, methane, and carbon dioxide $[17,19]$, and propionic acid was important for supplying electron flow [17]. Gorris et al. [17] noticed that complete degradation of propionic acid was observed when low concentration of acetic acid (less than $100 \mathrm{mg} / \mathrm{L}$ ) existed and high concentration of acetic acid $(4,700 \mathrm{mg} / \mathrm{L})$ blocked the degradation of propionic acid. Many agreed that higher concentration of acetic acid inhibited the degradation of propionic acid $[17,21]$ and inhibited the acetate-utilizing 


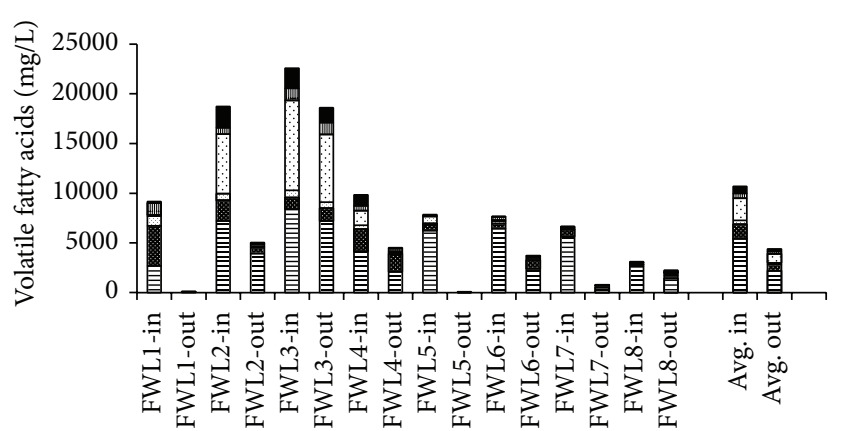

(a) FWL

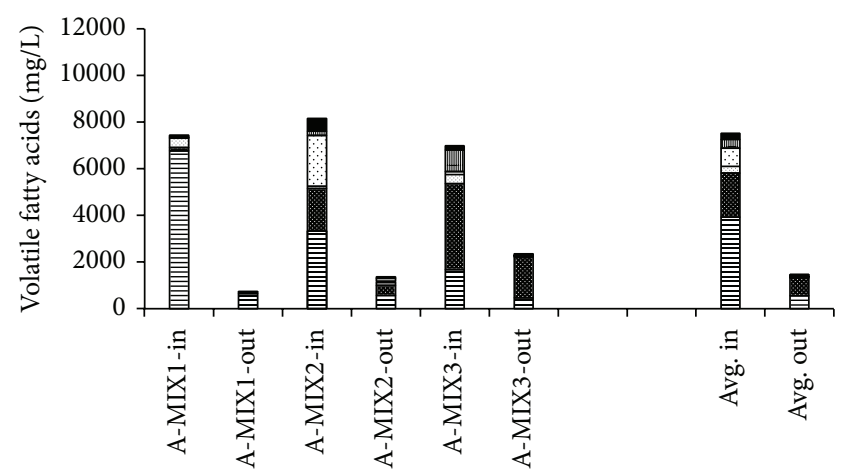

(b) A-MIX

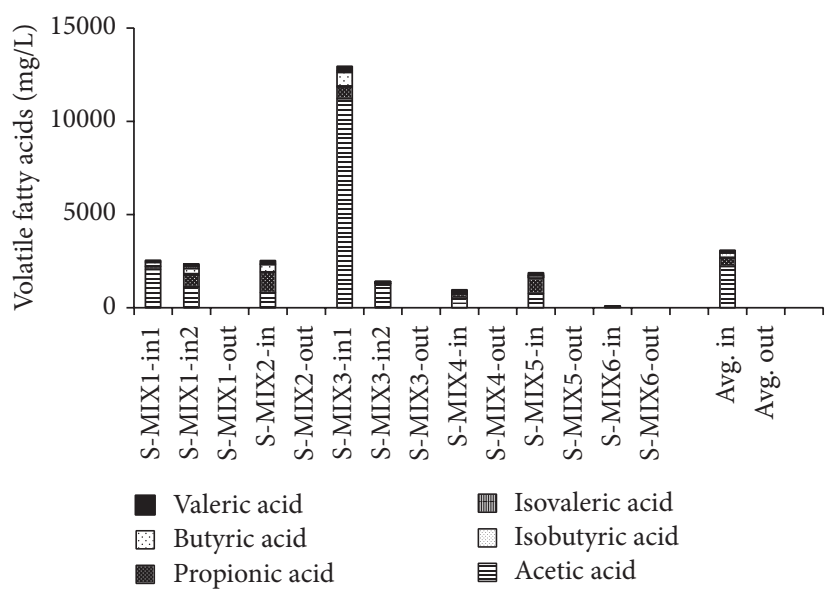

(c) S-MIX

FIGURE 4: Volatile fatty acids from each anaerobic digestion facility with different feed wastes.

methanogenic bacteria [39]. The accumulation of propionic acid might indicate the sign of disturbance of the process $[17,23,40]$. Björnsson et al. [23] reported that accumulation of propionic acid is closely related to the concentration of hydrogen; therefore hydrogen concentration could be a possible parameter to monitor the accumulation of volatile fatty acid $[23,26]$. Some studies have found that propionic acid should be treated as a toxic volatile fatty acid in anaerobic digester and the methanogenic bacteria have been shown vulnerable to propionic acid concentration greater than $1,000 \sim 2,000 \mathrm{mg} / \mathrm{L}$ [19]. Although Gourdon and Vermande [41] observed no inhibitory effect of propionic acid even at $6,000 \mathrm{mg} / \mathrm{L}$ they agreed that the accumulation of propionic acid should be seen as the warning sign and should take the attention of the process before it would cause a disturbance. Also Ahring et al. [22] suggested that volatile fatty acid should be used as indicators of imbalance of the process rather than an inhibitor. Therefore the volatile fatty acid should be treated as a monitoring parameter rather than an inhibitor.

Direct comparison with the literature was impossible in this study due to different system and operational conditions; however the effect of acetic acid on degradation of propionic acid and resulting production of methane as the end product has been reported. McCarty and Smith [27] suggested that the propionic acid accumulation appeared to predominate in the complex waste and the high concentration of propionic acid in FWL and A-MIX might be related to this finding. Several studies have found that OFMSW tended to produce long volatile fatty acids due to the presence of high level of protein and fat contents and they can lead to operational problems and instability of the digestion performance; therefore codigestion is recommended to alleviate this adverse effect and improve the efficiency of the process [15, 27]. Volatile solid removal rate of FWL3 was lowest, and this might indicate instability of the digestion performance and the methanogenic bacterial activity. Further study is required to conclude the effect; however better degradation of propionic acid has been noticed when lower concentration of acetic acid was found in S-MIX.

Figure 5 shows the relationship between volatile fatty acid concentration and volatile solids removal rate on the FWLs. It showed a linear relationship between volatile fatty acid concentration and volatile solid removal rate. According to this linear relationship, volatile fatty acid concentration should be below 4,000 mg/L in order to meet the Korean guideline of $65 \%$ volatile solid removal rate on the FWL. As A-MIX and S-MIX were without the guideline of volatile solid removal rate as well as with very low volatile solid removal rate, this relationship was analyzed except for them. In addition, the average volatile fatty acids of even the inlets of A-MIX and 


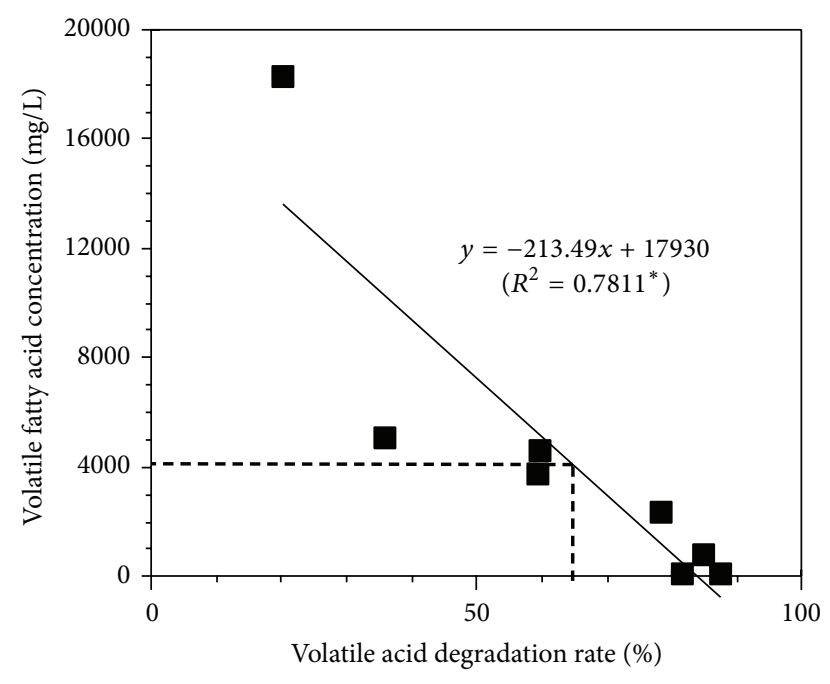

FIGURE 5: Relationship between volatile solid removal rate and volatile fatty acid concentration. * denotes significance at 5.0\% level.

S-MIX were very lower, approximately $1 / 2 \sim 1 / 4$, compared to the volatile fatty acids of FWLs (Figure 4). Therefore without considering $65 \%$ of volatile solid removal rate, limiting volatile fatty acid concentration to below $4,000 \mathrm{mg} / \mathrm{L}$ still seemed a reasonable approach to control the performance of the anaerobic digestion process. However considering 4 facilities (FWL) with volatile solid removal rate that were higher than 70\%, below $4,000 \mathrm{mg} / \mathrm{L}$ should be recommended. This relationship was observed from this specific study and it might not be applicable to all. More detailed study of each volatile fatty acid component is necessary to underpin the effect of the volatile fatty acid concentration on anaerobic degradation rate of the anaerobic digestion facilities. In addition, volatile acid/alkalinity ratio has been used to monitor the performance of anaerobic digestion process [24] and further study of volatile acid/alkalinity ratio as well as other parameters should be considered. Additionally further study of volatile fatty acids in comparison with microbial community is necessary to understand the microbial activities in terms of the series of reactions involved.

\section{Conclusions}

In Korea, there is lack of information on the field data for operation of anaerobic digestion facilities treating food waste leachate, especially for operational parameter for checklist of troubleshooting. This study evaluated the effect of volatile fatty acid concentration on volatile solid removal rate and investigated the relationship between them. The volatile solid removal rates of field anaerobic digestion facilities with food waste leachate were evaluated and the average volatile solid removal rates were below the Korean guideline of $65 \%$. In order to meet the Korean guideline of $65 \%$ volatile solid removal rate, volatile fatty acid concentrations should remain below $4,000 \mathrm{mg} / \mathrm{L}$ on the field anaerobic digestion facilities treating FWL. Volatile fatty acid concentrations should be used as an important operational parameter to control and manage the anaerobic digestion process.

\section{Conflict of Interests}

The authors declare that there is no conflict of interests regarding the publication of this paper.

\section{Acknowledgment}

This work was supported by the National Research Foundation of Korea grant funded by the Korea Government (Ministry of Education, Science and Technology) [NRF2014R1A1A2007515].

\section{References}

[1] Y.-M. Ahn, J. Wi, J.-K. Park, S. Higuchi, and N.-H. Lee, "Effects of Pre-aeration on the anaerobic digestion of sewage sludge," Environmental Engineering Research, vol. 19, no. 1, pp. 59-66, 2014.

[2] B. S. Lee, S. C. Nam, and W. Namkoong, "An evaluation of biogas production efficiencies from mechanically pretreated food waste and primary sewage sludge mixture by food waste mixing ratio through single stage anaerobic co-biogasfication," Journal of Korea Society of Waste Management, vol. 28, pp. 648660, 2011.

[3] F. Cui, S. Lee, and M. Kim, "Removal of organics and nutrients from food wastewater using combined thermophilic two-phase anaerobic digestion and shortcut biological nitrogen removal," Water Research, vol. 45, no. 16, pp. 5279-5286, 2011.

[4] B. V. Kim and J. H. Kwon, “Treatment of high-concentration swine wastewater by anaerobic digestion and an aquatic plant system," Environmental Engineering Research, vol. 11, no. 3, pp. 134-142, 2006.

[5] I. Siegert and C. Banks, "The effect of volatile fatty acid additions on the anaerobic digestion of cellulose and glucose in batch reactors," Process Biochemistry, vol. 40, no. 11, pp. 3412-3418, 2005.

[6] C. H. An, G.-H. Huang, Y. Yao, W. Sun, and K. An, "Performance of in-vessel composting of food waste in the presence of coal ash and uric acid," Journal of Hazardous Materials, vol. 203-204, pp. 38-45, 2012.

[7] G. K. Kafle, S. H. Kim, and B. S. Shin, "Anaerobic digestion treatment for the mixture of chinese cabbage waste juice and swine manure," Journal of Biosystems Engineering, vol. 37, no. 1, pp. 58-64, 2012.

[8] F. A. Nicholson, S. R. Smith, B. J. Alloway, C. Carlton-Smith, and B. J. Chambers, "An inventory of heavy metals inputs to agricultural soils in England and Wales," The Science of the Total Environment, vol. 311, no. 1-3, pp. 205-219, 2003.

[9] X. Fonoll, S. Astals, J. Dosta, and J. Mata-Alvarez, "Anaerobic codigestion of sewage sludge and fruit wastes: evaluation of the transitory states when the co-substrate is changed," Chemical Engineering Journal, vol. 262, pp. 1268-1274, 2015.

[10] C. Ratanatamskul, G. Onnum, and K. Yamamoto, "A prototype single-stage anaerobic digester for co-digestion of food waste and sewage sludge from high-rise building for on-site biogas production," International Biodeterioration \& Biodegradation, vol. 95, pp. 176-180, 2014. 
[11] S.-F. Chiu, J.-Y. Chiu, and W.-C. Kuo, "Biological stoichiometric analysis of nutrition and ammonia toxicity in thermophilic anaerobic co-digestion of organic substrates under different organic loading rates," Renewable Energy, vol. 57, pp. 323-329, 2013.

[12] S. H. Kim, S. K. Han, and H. S. Shin, "Feasibility of biohydrogen production by anaerobic co-digestion of food waste and sewage sludge," International Journal of Hydrogen Energy, vol. 29, no. 15, pp. 1607-1616, 2004.

[13] E. Iacovidou, D.-G. Ohandja, and N. Voulvoulis, "Food waste co-digestion with sewage sludge-realising its potential in the UK," Journal of Environmental Management, vol. 112, pp. 267$274,2012$.

[14] T. Yamashiro, S. A. Lateef, C. Ying et al., "Anaerobic co-digestion of dairy cow manure and high concentrated food processing waste," Journal of Material Cycles and Waste Management, vol. 15, no. 4, pp. 539-547, 2013.

[15] C. Zhang, G. Xiao, L. Peng, H. Su, and T. Tan, "The anaerobic co-digestion of food waste and cattle manure," Bioresource Technology, vol. 129, pp. 170-176, 2013.

[16] KMOE, The Standard Methods for Testing Water, Ministry of Environment (South Korea), Sejong City, Republic of Korea, 2005.

[17] L. G. M. Gorris, J. M. A. van Deursen, C. van der Drift, and G. D. Vogels, "Inhibition of propionate degradation by acetate in methanogenic fluidized bed reactors," Biotechnology Letters, vol. 11, no. 1, pp. 61-66, 1989.

[18] L. Appels, J. Baeyens, J. Degrève, and R. Dewil, "Principles and potential of the anaerobic digestion of waste-activated sludge," Progress in Energy and Combustion Science, vol. 34, no. 6, pp. 755-781, 2008.

[19] K. C. Wijekoon, C. Visvanathan, and A. Abeynayaka, "Effect of organic loading rate on VFA production, organic matter removal and microbial activity of a two-stage thermophilic anaerobic membrane bioreactor," Bioresource Technology, vol. 102, no. 9, pp. 5353-5360, 2011.

[20] D. T. Hill, S. A. Cobb, and J. P. Bolte, "Using volatile fatty acid relationships to predict anaerobic digester failure," Transactions of the American Society of Agricultural Engineers, vol. 30, no. 2, pp. 496-501, 1987.

[21] A. J. Mawson, R. L. Earle, and V. F. Larsen, "Degradation of acetic and propionic acids in the methane fermentation," Water Research, vol. 25, no. 12, pp. 1549-1554, 1991.

[22] B. K. Ahring, M. Sandberg, and I. Angelidaki, "Volatile fatty acids as indicators of process imbalance in anaerobic digestors," Applied Microbiology and Biotechnology, vol. 43, no. 3, pp. 559565, 1995.

[23] L. Björnsson, M. Murto, and B. Mattiasson, "Evaluation of parameters for monitoring an anaerobic co-digestion process," Applied Microbiology and Biotechnology, vol. 54, no. 6, pp. 844849, 2000.

[24] F. Raposo, R. Borja, M. A. Martín, A. Martín, M. A. de la Rubia, and B. Rincón, "Influence of inoculum-substrate ratio on the anaerobic digestion of sunflower oil cake in batch mode: process stability and kinetic evaluation," Chemical Engineering Journal, vol. 149, no. 1-3, pp. 70-77, 2009.

[25] Y. Li, S. Y. Park, and J. Zhu, "Solid-state anaerobic digestion for methane production from organic waste," Renewable and Sustainable Energy Reviews, vol. 15, no. 1, pp. 821-826, 2011.

[26] H. B. Nielsen, H. Uellendahl, and B. K. Ahring, "Regulation and optimization of the biogas process: propionate as a key parameter," Biomass and Bioenergy, vol. 31, no. 11-12, pp. 820 830, 2007.

[27] P. L. McCarty and D. P. Smith, "Anaerobic wastewater treatment," Environmental Science \& Technology, vol. 20, no. 12, pp. 1200-1206, 1986.

[28] S. Borowski, J. Domański, and L. Weatherley, "Anaerobic codigestion of swine and poultry manure with municipal sewage sludge," Waste Management, vol. 34, no. 2, pp. 513-521, 2014.

[29] M. Anjum, A. Khalid, T. Mahmood, and M. Arshad, "Anaerobic co-digestion of municipal solid organic waste with melon residues to enhance biodegradability and biogas production," Journal of Material Cycles and Waste Management, vol. 14, no. 4, pp. 388-395, 2012.

[30] E. A. Scano, C. Asquer, A. Pistis, L. Ortu, V. Demontis, and D. Cocco, "Biogas from anaerobic digestion of fruit and vegetable wastes: experimental results on pilot-scale and preliminary performance evaluation of a full-scale power plant," Energy Conversion and Management, vol. 77, pp. 22-30, 2014.

[31] R. Ganesh, M. Torrijos, P. Sousbie, J. P. Steyer, A. Lugardon, and J. P. Delgenes, "Anaerobic co-digestion of solid waste: effect of increasing organic loading rates and characterization of the solubilised organic matter," Bioresource Technology, vol. 130, pp. 559-569, 2013.

[32] H. M. El-Mashad and R. Zhang, "Biogas production from co-digestion of dairy manure and food waste," Bioresource Technology, vol. 101, no. 11, pp. 4021-4028, 2010.

[33] V. Cabbai, M. Ballico, E. Aneggi, and D. Goi, "BMP tests of source selected OFMSW to evaluate anaerobic codigestion with sewage sludge," Waste Management, vol. 33, no. 7, pp. 1626-1632, 2013.

[34] C. Cavinato, D. Bolzonella, P. Pavan, F. Fatone, and F. Cecchi, "Mesophilic and thermophilic anaerobic co-digestion of waste activated sludge and source sorted biowaste in pilot- and fullscale reactors," Renewable Energy, vol. 55, pp. 260-265, 2013.

[35] APHA, AWWA, and WEF, Standard Methods for the Examination of Water and Wastewater, American Public Health Association, American Water Works Association, Water Environment Federation, Washington, DC, USA, 22nd edition, 1998.

[36] A. Rueda, I. Seiquer, M. Olalla, R. Giménez, L. Lara, and C. Cabrera-Vique, "Characterization of fatty acid profile of argan oil and other edible vegetable oils by gas chromatography and discriminant analysis," Journal of Chemistry, vol. 2014, 8 pages, 2014.

[37] E. d. Braga, J. d. Malveira, M. A. Milhome, M. D. de Aquino, and R. F. Nascimento, "Characterization of the fatty acids present in wastewaters from production of biodiesel tilapia," Journal of Chemistry, vol. 2015, Article ID 265160, 6 pages, 2015.

[38] S. Borowski and L. Weatherley, "Co-digestion of solid poultry manure with municipal sewage sludge," Bioresource Technology, vol. 142, pp. 345-352, 2013.

[39] D. J. Ju, C. S. Jung, J. J. Park, I. G. Byun, and T. J. Park, "Methane production and microbial community from vs concentration in anaerobically co-digesting of food waste and sewage sludge," in Proceedings of the Spring conference, Ulsan, Environmental Engineering Science, pp. 443-450, 2008, (Korean).

[40] M. Murto, L. Björnsson, and B. Mattiasson, "Impact of food industrial waste on anaerobic co-digestion of sewage sludge and pig manure," Journal of Environmental Management, vol. 70, no. 2, pp. 101-107, 2004.

[41] R. Gourdon and P. Vermande, "Effects of propionic acid concentration on anaerobic digestion of pig manure," Biomass, vol. 13, no. 1, pp. 1-12, 1987. 

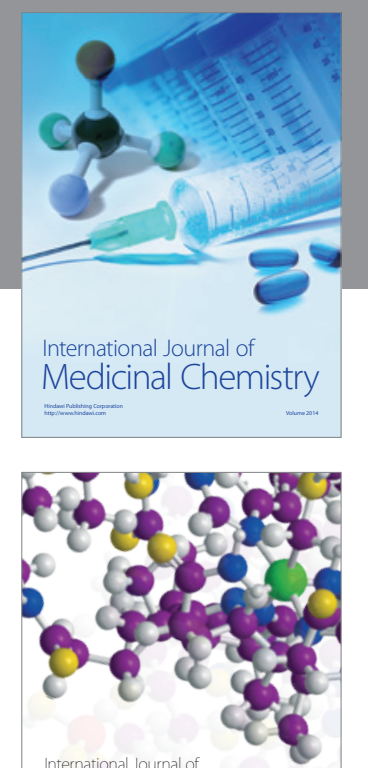

\section{Carbohydrate} Chemistry

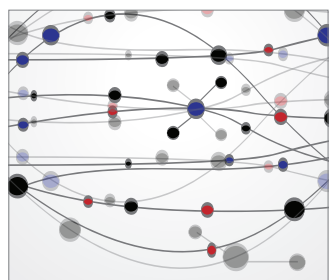

The Scientific World Journal
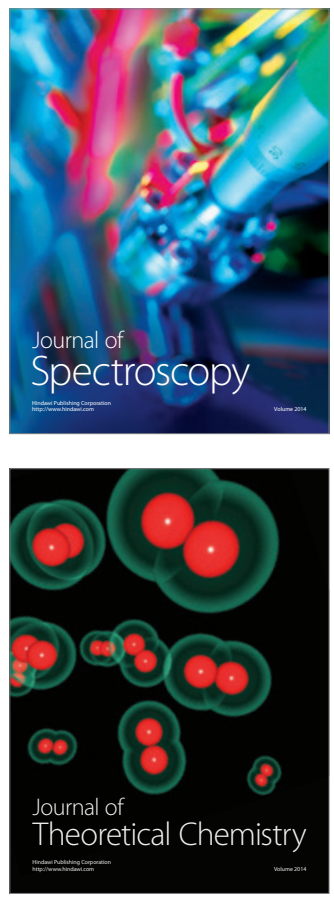
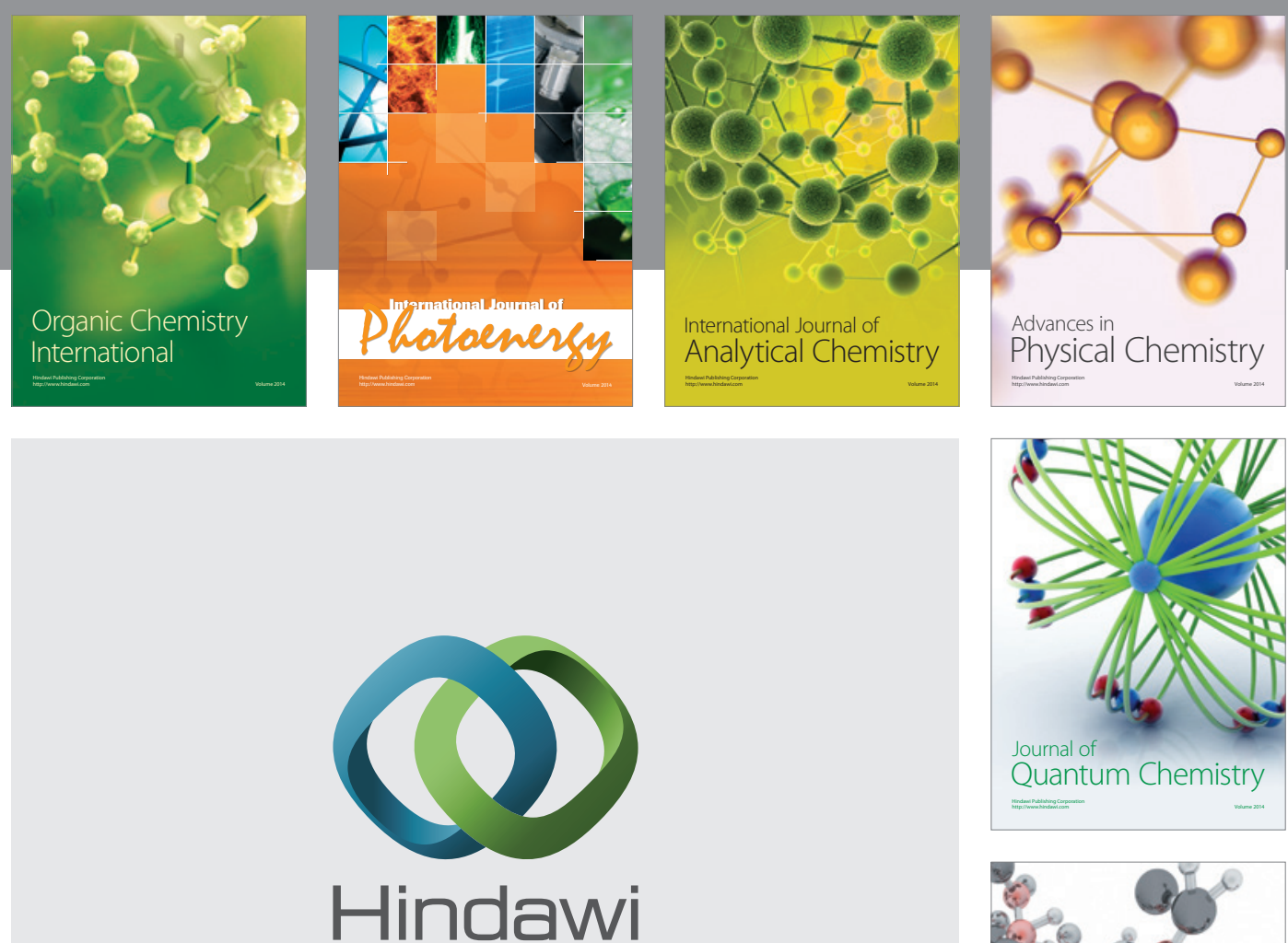

Submit your manuscripts at

http://www.hindawi.com

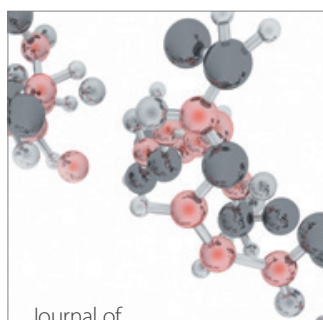

Analytical Methods

in Chemistry

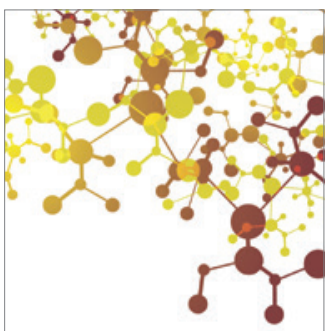

Journal of

Applied Chemistry

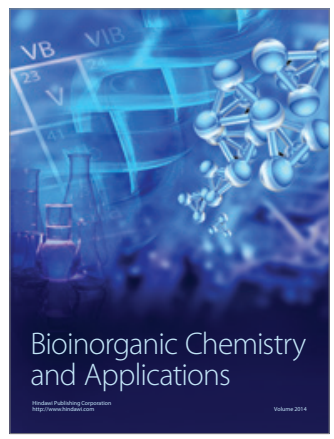

Inorganic Chemistry
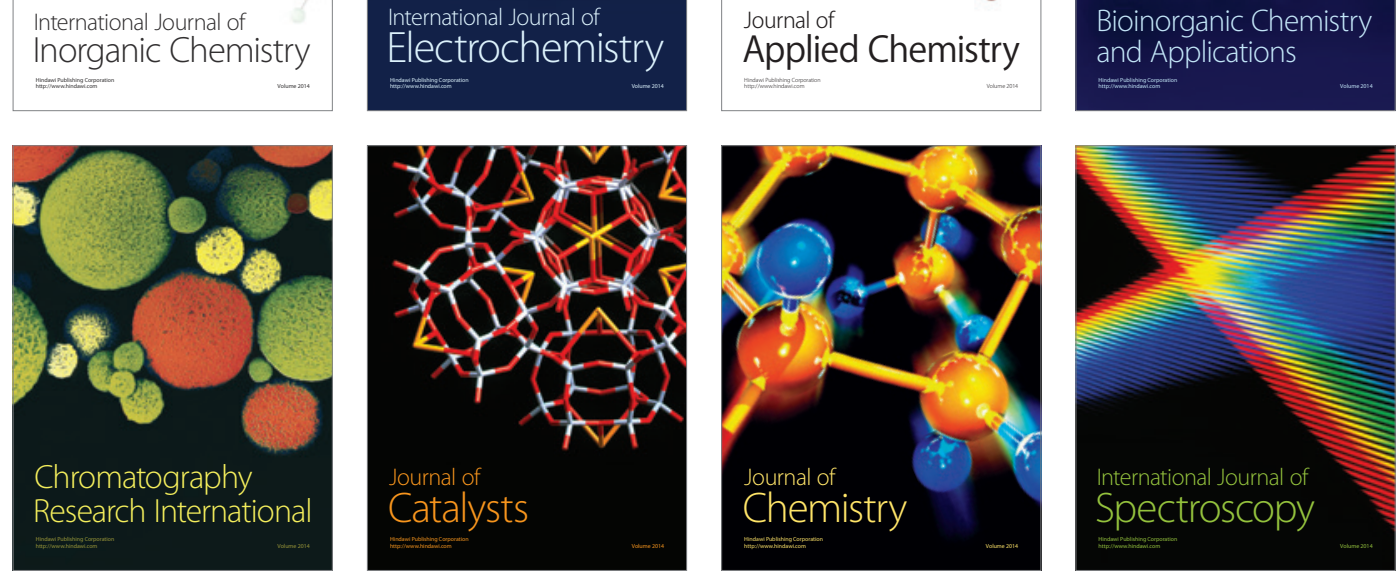